Pobrane z czasopisma Annales I - Philosophy and Sociology http://philosophia.annales.umcs.pl Data: 26/04/2023 15:50:37

DOI: $10.17951 / \mathrm{i} .2018 .43 .2 .73-92$

A N N A L E S

UNIVERSITATIS MARIAE CURIE-SKŁODOWSKA

LUBLIN - POLONIA

VOL. XLIII, 2

SECTIO I

2018

\author{
ANDRZEJ KUBIĆ \\ ORCID: 0000-0002-8834-7134 \\ Uniwersytet Marii Curie-Skłodowskiej w Lublinie
}

\title{
„Niezdeterminowanie” granic poznania w znaturalizowanym relatywizmie pojęciowym W.V.O. Quine'a
}

"Undetermined" Limits of Knowledge in the Naturalized Conceptual Relativism of W.V.O. Quine

\section{WPROWADZENIE}

Zagadnieniu granic poznania W.V.O. Quine poświęcił odrębny esej ${ }^{1}$. Główną intencją tego tekstu - jak sam zaznacza - jest jednak przede wszystkim analiza i modyfikacja tytułowego problemu, a nie próba udzielenia nań odpowiedzi ${ }^{2}$. Według Quine’a, pytając o to, czy istnieją rzeczy, których człowiek nigdy nie mógłby poznać, pytamy w istocie, czy są pytania, na które człowiek nigdy nie mógłby odpowiedzieć, albo jeszcze dokładniej: czy są pytania, na które z zasady nie można odpowiedzieć. Krótko mówiąc, zagadnienie to można zredukować do kontekstu językowego. W takim ujęciu pytania, na które z zasady nie można odpowiedzieć, muszą zostać uznane za pozbawione sensu.

\section{OD ONTOLOGII DO LINGWISTYKI}

Systematyczna wykładnia koncepcji Quine’a w dużej mierze pokrywa się z jej genezą chronologiczną, dlatego najlepiej rozpocząć jej prezentację od ukazania sposobu wchłonięcia problematyki ontologicznej przez teorię języka i pozna-

1 W.V.O. Quine, The Limits of Knowledge (1972), [w:] The Ways of Paradox and Other Essays, Massachusetts-London 1976; idem, Granice wiedzy, [w:] Granice wiedzy i inne eseje filozoficzne, Warszawa 1986.

2 Ibidem, s. 17. 
Pobrane z czasopisma Annales I - Philosophy and Sociology http://philosophia.annales.umcs.pl Data: 26/04/2023 15:50:37

nia, który po raz pierwszy został przedstawiony w eseju zatytułowanym $O$ tym, co istnieje $e^{3}$.

W tym eseju Quine narzuca lingwistyczną sieć na całą ontologię, wypowiadając swoją głośną później formułę: „Być, to być wartością zmiennej”4 Tę na pozór wieloznacznie i enigmatycznie brzmiącą zasadę Quine uzasadnia na bazie przetransformowanej Russellowskiej teorii deskrypcji (była ona metodą przekształcania wyrażeń nazwowych w predykaty). Zostaje ona tutaj rozszerzona do tego stopnia, że umożliwia wyeliminowanie wszystkich terminów indywiduowych. Nazwy są zupełnie bez znaczenia dla kwestii ontologicznych, można bowiem (jak np. w przypadku „Pegaza” i „pegazowania”) zawsze przekształcić je w deskrypty, które dadzą się wyeliminować, czyli wszystko, co można powiedzieć, używając nazw, można również powiedzieć w języku, w którym nazwy w ogóle nie funkcjonują. Dlatego też „być uznanym za przedmiot istniejący to po prostu i tylko tyle, co być zaliczonym do wartości zmiennych. W terminach tradycyjnej gramatyki można sformułować to twierdzenie następująco: być to to samo, co być w zakresie przedmiotowego odniesienia jakiegoś zaimka"s. Quine uważa zaimki za podstawowy środek językowego odnoszenia się do przedmiotów, rzeczowniki zaś pełnią w tej sytuacji funkcję czegoś, co można by określić mianem „za-zaimków”. Cała ontologia, w każdej postaci, jest zatem wyznaczana przez takie zmienne kwantyfikacji, jak „coś”, „nic” lub „wszystko”. Zdaniem Quine'a taka transformacja sporów ontologicznych do postaci semantycznej pozwoli rozstrzygnąć wiele nierozwiązywalnych do tej pory problemów, stwarzając wspólną podstawę do dyskusji.

W eseju tym autor stawia pytanie, w jaki sposób należy dokonywać wyboru między konkurencyjnymi teoriami ontologicznymi. W odpowiedzi stwierdza, że przyjęcie danego systemu ontologii ma stanowić analogię do sposobu wyboru teorii naukowej, gdzie za kryterium przyjmuje się najprostszy aparat pojęciowy, pozwalający objąć i uporządkować chaotyczny zbiór danych doświadczenia. Dalej dodaje jednak, że prostota nie jest kryterium całkowicie jednoznacznym i wyraźnym, może się bowiem zdarzyć, że kryterium temu w sposób równoważny będzie odpowiadało kilka aparatur pojęciowych ${ }^{6}$.

Tezy zawarte w eseju On What There Is Quine systematyczne rozwijał w następnych pismach ${ }^{7}$; ich ostatnią wersję zawiera książka Na tropach prawdy (Pursuit of Truth) ${ }^{8}$.

\footnotetext{
Idem, O tym, co istnieje, [w:] Z punktu widzenia logiki, Warszawa 2000, s. 29-48.

Ibidem, s. 44.

Ibidem, s. 41.

Ibidem, s. 45.

Zob. m.in. idem, Ontological Relativity and Other Essays, Cambridge-London 1977.

Idem, Pursuit of Truth, Cambridge 1992; idem, Na tropach prawdy, Warszawa 1997.
} 
Zmienne związane (czy też potocznie: zaimki) spełniają jeszcze dwie istotne funkcje w systemie ontologicznym Quine'a. Pierwszą z nich jest reifikacja, w której zmienne związane pełnią rolę idealnych węzłów służących do zogniskowania kategorycznych zdań obserwacyjnych. Wiążą one odniesienia tych zdań z przedmiotami pobudzającymi nasze powierzchnie sensoryczne, np. „Coś kotuje i jest białe i stoi-przed-psem i jeży się"9. Starając się sformułować to nieco prościej, można by powiedzieć, że początkiem procesu rozwojowego człowieka są pobudzenia sensoryczne i odpowiadające im zdania obserwacyjne. Natomiast urzeczowienie poznawanego świata odbywa się poprzez powiązanie tych zdań poprzez zaimki (lub zmienne związane).

Jednakże najważniejszą rolą zmiennych związanych jest umożliwienie „funkcji pełnomocnictwa", która jest metodą dokonywania dowolnych jedno-jednoznacznych transformacji przedmiotów należących do teorii ontologicznej (naukowej) na terminy należące do teorii alternatywne ${ }^{10}$. Każdemu przedmiotowi „,x” $\mathrm{z}$ obszaru ontologii $\mathrm{O}_{1}$ możemy poprzez reinterpretację przyporządkować przedmiot „fx”, będący jego ,pełnomocnikiem” w ontologii „O $\mathrm{O}_{2}$. Skorelowane w ten sposób ontologie pozostają empirycznie równoważne, tzn. zdania obserwacyjne są powiązane tymi samymi, co przedtem, pobudzeniami zmysłowymi z nienaruszeniem związków logicznych ${ }^{11}$. Jest to teza lingwistycznego relatywizmu ontologicznego.

Ontologia zatem funkcjonuje jedynie w roli środka pomocniczego lingwistycznej epistemologii. Można ją porównać do gramatyki - obie stanowią jedynie ludzką, ciągle modyfikowaną propozycję pojęciowego uporządkowania świata.

\section{ATAK NA DWA DOGMATY EMPIRYZMU I IDEA EMPIRYZMU HOLISTYCZNEGO}

Esej Dwa dogmaty empiryzmu ${ }^{12}$ przyniósł Quine'owi największą sławę, do tej pory postawione w nim problemy są aktualne. Owe dwa dogmaty to: 1) przekonanie o zachodzeniu fundamentalnej dychotomii pomiędzy zdaniami anali-

$9 \quad$ Ibidem, s. 53-56.

10 Ibidem, s. 57.

11 Najbardziej radykalną formę względności ontologicznej implikuje twierdzenie Löwenheima-Skolema w wersji wzmocnionej przez D. Hilberta i P. Bernaysa (zob. idem, Methods of Logic, Cambridge 1982, s. 209-211). Według Quine'a „twierdzenie to pozwala nam zreinterpretować predykaty z zachowaniem prawdziwości zdań w taki sposób, że uniwersum będzie się składało wyłącznie z liczb naturalnych $0,1,2, \ldots$ ” (zob. idem, Na tropach..., s. 58). Jednocześnie zaznacza, że ze względów praktycznych i heurystycznych zastosowanie twierdzenia Löwenheima-Skolema w jego interpretacji rozwoju nauki jest zbędne, ponieważ do tego celu w zupełności wystarczą wymienione wcześniej funkcje pełnomocnictwa (ibidem, s. 59).

12 Idem, Two Dogmas of Empiricism, "Philosophical Review" 1951, Vol. 60(1), DOI: https:// doi.org/10.2307/2181906; idem, Dwa dogmaty empiryzmu, [w:] Z punktu widzenia..., s. 49-76. 
Pobrane z czasopisma Annales I - Philosophy and Sociology http://philosophia.annales.umcs.pl Data: 26/04/2023 15:50:37

76 Andrzej Kubić

tycznymi (opartymi na znaczeniu i niezależnymi od faktów) a zdaniami syntetycznymi (opartymi na faktach) oraz 2) ściśle związane z pierwszym dogmatem redukcjonistyczne założenia weryfikacyjnej teorii znaczenia.

Quine zaczyna od krótkiej prezentacji dziejów pojęcia analityczności, poczynając od rozróżnienia G.W. Leibniza na prawdy rozumu i prawdy o faktach, poprzez podział D. Hume'a na stosunki między ideami i fakty, aż do Kantowskiego podziału, gdzie zdanie analityczne jest definiowane jako prawdziwe na mocy swojego znaczenia, a więc niezależnie od faktów ${ }^{13}$.

Biorąc za punkt wyjścia to określenie, Quine zaczyna od analizy pojęcia znaczenia. Uważa, że główną przyczyną postulowania i wprowadzania znaczeń jako rzekomych bytów jest powszechne nierozróżnianie znaczenia (intensji, konotacji) od oznaczania (ekstensji, denotacji). Po czym twierdzi, iż po dokonaniu tego rozróżnienia wyraźnie uwidacznia się możliwość odrzucenia znaczeń jako niejasnych bytów pośredniczących, natomiast sam problem teorii znaczenia przyjmuje postać kwestii synonimiczności wyrażeń i analityczności zdań.

Zaczynając analizę tego zagadnienia, Quine dzieli zdania analityczne na dwie klasy. Pierwszymi są zdania logicznie prawdziwe, oparte na znaczeniu funktorów prawdziwościowych, np. (1) „Żaden nieżonaty mężczyzna nie jest żonaty”. Druga grupa zdań oparta jest na pojęciu synonimu, np. (2) „Żaden kawaler nie jest żonaty". Ich prawdziwość wynika ze znaczenia użytych w nich terminów w tym sensie, że można je przekształcać w prawdy logiczne przez wzajemne zastępowanie wyrażeń synonimicznych, np. słowo „kawaler” można zastąpić wyrażeniem „nieżonaty mężczyzna”, co przekształcałoby zdanie (2) w zdanie (1). Nie jest to jednak zadowalające rozwiązanie, ponieważ pojecie synonimu wymaga wyjaśnienia w nie mniejszym stopniu niż pojęcie analityczności. W związku z tym Quine analizuje trzy różne możliwości wytłumaczenia natury synonimiczności: poprzez odwołanie się do definicji, wymienialność wyrażeń we wszelkich kontekstach (salva veritate) oraz konstrukcje oparte na językach formalnych.

I tak definicja leksykograficzna, będąc jedynie sprawozdaniem z funkcjonowania synonimiczności zaobserwowanej, nie może być traktowana jako jej podstawa. Z kolei definiowanie, nazwane przez R. Carnapa eksplikacja, której celem miało być ulepszenie definiendum poprzez wyklarowanie jego znaczenia, zakładało uprzednią synonimiczność kontekstową. Definicja ta zawdzięczała więc swoją funkcję eksplikacyjną synonimom występującym w języku przed jej sformułowaniem. Szczególnym przypadkiem jest definicja projektująca, która

13 Zestawienie i omówienie różnych historycznych pojęć analityczności zob. w: J. Woleński, Metamatematyka i epistemologia, Warszawa 1993, s. 121 i nast. Por. także kwestie dotyczące krytyki analityczności Quine'a - ibidem, s. 147 i nast. 
Pobrane z czasopisma Annales I - Philosophy and Sociology http://philosophia.annales.umcs.pl Data: 26/04/2023 15:50:37

„Niezdeterminowanie” granic poznania w znaturalizowanym relatywizmie pojęciowym...

konwencjonalnie „ukuwa” synonimiczność definiendum z definiensem. Podsumowując, wszystkie odmiany definicji zakładają już synonimiczność w jakimś określonym sensie, a więc nie mogą być podstawą jej wyjaśnienia ${ }^{14}$.

Następnie Quine bierze pod lupę, jako możliwą genezę synonimiczności, wzajemną wymienialność dwóch form językowych, we wszystkich możliwych kontekstach, bez zmiany wartości logicznej tych kontekstów, czyli wymienialność salva veritate. Poszukując na tej płaszczyźnie źródła synonimiczności dla wyrażeń typu „kawaler” i „nieżonaty mężczyzna”, którą określa mianem poznawczej, zauważa, iż w przypadku języka ekstensjonalnego nie mamy pewności, czy tożsamość ekstensji tych wyrażeń nie jest faktem całkowicie przypadkowym. Natomiast na gruncie języka intensjonalnego (zawierającego zwroty typu ,jest konieczne, że" i usuwające zagrożenie przypadkowością), chociaż wymienialność salva veritate stanowi wystarczający warunek synonimiczności poznawczej, to język taki jest zrozumiały tylko wówczas, gdy już uprzednio zrozumiałe jest pojęcie analityczności, które miało wyjaśnić synonimiczność poznawczą. Według Quine’a w argumentacji tej pojawia się błąd w rodzaju petitio principii ${ }^{15}$.

Fakt ten zmusza go do ponownego zajęcia się pojęciem analityczności. Zaczyna od przeciwstawienia się popularnej wśród neopozytywistów tezie mówiącej o tym, że problemy z jednoznacznym podziałem zdań analitycznych i syntetycznych są cechą języka potocznego. Są oni przy tym przekonani, że precyzyjne języki sztuczne, oparte na wymienionych explicite „regułach semantycznych", są pozbawione tego mankamentu. Aby dowieść, że się mylą, Quine poddaje analizie sformułowany przez Carnapa model sztucznego języka $\mathrm{L}_{0}$, którego reguły semantyczne mają postać wyliczenia wszystkich zdań analitycznych $\mathrm{w}_{0}$. Reguły te ponadto informują, że takie a takie zdania, i tylko one, są analityczne w $\mathrm{L}_{0}$. Zasadnicza trudność, jaka tu się pojawia, polega na niezrozumiałości zawartego w tych regułach słowa ,,analityczny”. „Krótko mówiąc, aby zrozumieć regułę zaczynającą się od słów »Zdanie $\mathrm{S}$ jest analityczne w języku $\mathrm{L}_{0}$ wtedy i tylko wtedy, gdy...«, trzeba najpierw zrozumieć ogólny termin względny »analityczne w«, a więc rozumieć zwrot »S jest analityczne w L, gdzie S i L są zmienne«" "16. Dalej zaś pokazuje, że termin „reguła semantyczna języka” w takim samym stopniu wymaga wyjaśnienia, co zwrot ,analityczne w". Reguły semantyczne, które wyznaczają zdania analityczne jakiegoś języka sztucznego, nie mogą przyczynić się do zrozumienia pojęcia analitycz-

14 W.V.O. Quine, Dwa dogmaty..., s. 53-55.

15 Ibidem, s. 56-61.

16 Ibidem, s. 63. 
Pobrane z czasopisma Annales I - Philosophy and Sociology http://philosophia.annales.umcs.pl Data: 26/04/2023 15:50:37

78 Andrzej Kubić

ności, ponieważ ich przydatność jest uzależniona od wcześniejszego zrozumienia pojęcia analityczności ${ }^{17}$.

Klarownym podsumowaniem krytyki analityczności wydaje się następujący fragment:

Jest rzeczą oczywistą, że ogólnie rzecz biorąc, prawdziwość zdań zależy zarówno od języka, jak i od faktów pozajęzykowych. Zdanie „Brutus zabił Cezara” byłoby fałszywe, gdyby świat był pod pewnym względem inny, lecz byłoby fałszywe także w przypadku, gdyby słowo „zabił” znaczyło tyle, co „spłodził”. Dlatego właśnie jesteśmy skłonni zakładać ogólnie, że prawdziwość zdań daje się rozłożyć na komponent językowy i komponent faktualny. Przy tym założeniu wydaje się racjonalne sądzić, że w przypadku pewnych zdań ów komponent faktualny powinien być zerowy; byłyby to właśnie zdania analityczne. Lecz przy całej apriorycznej racjonalności tego pomysłu linia graniczna pomiędzy zdaniami analitycznymi i syntetycznymi po prostu nie została poprowadzona. Przekonanie, że rozróżnienie to jest w ogóle wykonalne, jest nieempirycznym dogmatem empirystów $[\ldots]^{18}$.

Następnie Quine przechodzi do krytyki drugiego dogmatu empiryzmu, który jednak wyraźnie łączy się z pierwszym. Jak wiadomo, znaczeniem zdania według weryfikacyjnej teorii znaczenia jest metoda empirycznego potwierdzania go lub podważania. Ponadto teoria ta głosi, że zdania są synonimiczne wtedy i tylko wtedy, gdy nie różnią się co do metody ich empirycznego potwierdzania lub podważania. W przypadku słuszności teorii weryfikacyjnej pojęcie analityczności, czyli pierwszy dogmat empiryzmu, zostałby więc uratowany.

Współcześni redukcjonistyczni weryfikacjoniści (Carnap i inni logiczni pozytywiści) jako przedmioty weryfikacji traktują zdania, a za swoje główne zadanie uważają wyróżnienie języka danych zmysłowych oraz opracowanie metody przekładu na ten język (zdanie po zdaniu) wszystkich innych sensownych wypowiedzi. Redukcjonizm ten sprowadza się do przekonania, iż każdemu zdaniu syntetycznemu odpowiada jednoznacznie określony zbiór możliwych zdarzeń zmysłowych, z których każde, realizując się, zwiększa prawdopodobieństwo tego zdania, oraz możliwy zbiór zdarzeń zmysłowych, które każdorazowo, realizując się, zmniejszają prawdopodobieństwo tego zdania. Dogmatem redukcjonizmu jest więc teza, że każde zdanie ujęte w izolacji od pozostałych zdań może w ogóle zostać potwierdzone lub podważone. $\mathrm{Z}$ kolei stanowisko przeciwne, w obrębie którego Quine sam się umiejscawia, głosi, że „nasze twierdzenia o świecie zewnętrznym stają przed trybunałem doświadczenia zmysłowego nie indywidualnie, lecz zbiorowo" $"$.

\footnotetext{
17 Ibidem, s. 65-66.

18 Ibidem, s. 66.

19 Ibidem, s. 70.
} 
Należy podkreślić, że od tego miejsca swojego najważniejszego tekstu Quine zarysowuje (w sposób, jak sam zaznacza, metaforyczny) jako pozytywną kontrargumentację przeciwko dogmatom empiryzmu zasadnicze dla całej jego filozofii i powiązane ze sobą idee empiryzmu holistycznego oraz instrumentalizmu i racjonalnego pragmatyzmu. Zaczynając od holizmu, nauka jako całość jest jednostką sensu empirycznego i pozostaje w podwójnej zależności od języka i od doświadczenia. Nauka jako całość oznacza tu całokształt wytworzonej przez ludzkość wiedzy i przekonań, od najbardziej przypadkowych prawd geografii i historii do najbardziej abstrakcyjnych praw fizyki, matematyki i logiki formalnej. Tak określoną naukę można porównać do jakiegoś pola siłowego, którego warunki brzegowe określa doświadczenie. W centralnej części tego obszaru wiedzy znajdują się analityczne prawa logiki, z doświadczeniem natomiast stykają się syntetyczne zdania obserwacyjne. Każdy konflikt z doświadczeniem na obrzeżach nauki powoduje odpowiednie do niego dostosowanie w jej wnętrzu. Polega ono na zmianie wartości logicznej niektórych zdań brzegowych lub centralnych, w tym również praw logiki stanowiących centralne elementy obszaru wiedzy. Nauka jako całość jest jednak na tyle niezdeterminowana przez doświadczenie (związki między poszczególnymi świadectwami a określonymi zdaniami z wnętrza nauki są wyłącznie pośrednie), iż dopuszczalna jest znaczna swoboda wyboru zdań, których wartość logiczna może być zmieniona. Innymi słowy, każde zdanie może obowiązywać niezależnie od doświadczenia, o ile wystarczająco zostanie przystosowana do niego reszta systemu i odwrotnie - żadne zdanie nie jest zabezpieczone przed rewizją (np. w celu interpretacji mechaniki kwantowej zaproponowano zrewidowanie logicznego prawa wyłączonego środka). Jedynym istotnym ograniczeniem przy zmianie wartości logicznej zdań jest zasada minimalnego naruszenia integralności całego systemu wiedzy ${ }^{20}$.

Z kolei deklaracja instrumentalizmu i relatywizmu ontologicznego wyraźnie zarysowuje się, kiedy Quine stwierdza, iż:

[...] schemat pojęciowy nauki jest w ostatecznym rachunku środkiem, który służy przewidywaniu przyszłego doświadczenia na podstawie doświadczenia minionego. Przedmioty fizyczne są pojęciowo wnoszone do sytuacji jako wygodne ogniwa pośredniczące - nie przez definiowanie ich w terminach doświadczenia, lecz jako nieredukowalne byty postulowane, porównywalne pod względem epistemologicznym z bogami Homera. Co do mnie, jako laicki naturalista wierzę w przedmioty fizyczne, nie wierzę natomiast w bogów Homera. Jednakże pod względem podstaw epistemologicznych bogowie różnią się od przedmiotów fizycznych tylko co do stopnia, nie zaś co

20 Wcześniej podobne (ale bardziej umiarkowane) poglądy głosił K. Ajdukiewicz. Zob. artykuł tego autora pt. Logika i doświadczenie, „Przegląd Filozoficzny” 1947, nr 1-4, s. 3-21. Szczegółowo na ten temat zob. H. Jakubiec, J. Woleński, Ajdukiewicz a Quine, „Zagadnienia Naukoznawstwa" 1983, nr 3, s. 309-320. 
do rodzaju. Obydwa te typy przedmiotów znalazły się w naszym poglądzie na świat jako twory ludzkie, byty postulowane. Mit przedmiotów fizycznych posiada głównie tę epistemologiczną przewagę nad innymi mitami, iż okazał się bardziej niż one skuteczny w roli narzędzia służącego nadaniu operatywnej struktury strumieniowi doświadczenia zmysłowego ${ }^{21}$.

I wreszcie naturalistyczny zwrot ku racjonalnemu pragmatyzmowi, lub też pragmatycznie racjonalny zwrot ku naturalizmowi, jest explicite wypowiedzianą konkluzją kończącą rozprawę Quine'a. Stwierdza on, że pragmatyzm innych filozofów znika na wyimaginowanej granicy pomiędzy tym, co analityczne i tym, co syntetyczne.

Obalając tę granicę, opowiadam się za pragmatyzmem bardziej konsekwentnym. Każdemu człowiekowi dane jest dziedzictwo nauki plus nieprzerwany strumień bodźców zmysłowych; względy, którymi kieruje się on, naruszając dziedzictwo nauki dla zharmonizowania go ze swymi doznaniami zmysłowymi, mają - o ile są racjonalne - charakter pragmatyczny ${ }^{22}$.

Bardzo istotną, chociaż może mniej naświetlaną konsekwencją zniesienia przez Quine’a granicy między zdaniami analitycznymi a syntetycznymi, było ponowne (po wykluczeniu jej przez neopozytywistów) zaliczenie do obszaru wiedzy ontologicznych teorii filozoficznych.

Podważenie przez Quine'a dychotomii analityczne - syntetyczne wywołało trwającą do dzisiaj burzę dyskusji, jednak za najbardziej konkluzywny uważa się kontrargument P. Grice'a i P.F. Strawsona (filozofów języka potocznego):

Istotny [...] punkt u Quine'a polega na tym, że nie ma absolutnej konieczności przyjęcia lub stosowania jakiegokolwiek schematu pojęciowego lub, dokładniej i przy wykorzystaniu pojęcia, które Quine odrzuciłby, nie istnieją zdania analityczne takie, że musimy mieć formy językowe mające sens wymagany dla wyrażenia takich zdań. Wszelako uznanie tego jest jedną rzeczą, a całkowicie inną jest utrzymywanie, że nie istnieją konieczności wewnątrz przyjmowanych lub stosowanych pojęciowych form albo też, jeszcze raz dokładniej, nie istnieją formy, którymi wyrażamy zdania analityczne ${ }^{23}$.

Z punktu widzenia naszych badań najistotniejsze i niewątpliwe jest to, że w Dwóch dogmatach empiryzmu Quine nakreślił mapę swoich późniejszych poglądów, których podstawowy kształt już się nie zmienił.

${ }^{21}$ W.V.O. Quine, Dwa dogmaty..., s. 73-74.

22 Ibidem, s. 75.

23 P. Grice, P. Srawson, In Defense of a Dogma, "The Philosophical Review" 1956, Vol. 65(2), DOI: https://doi.org/10.2307/2182828, s. 141-148, cyt. za: J. Woleński, Epistemologia, t. 2: Wiedza i poznanie, Kraków 2001, s. 118-119. 
Pobrane z czasopisma Annales I - Philosophy and Sociology http://philosophia.annales.umcs.pl Data: 26/04/2023 15:50:37

„Niezdeterminowanie” granic poznania w znaturalizowanym relatywizmie pojęciowym... 81

\section{BEHAWIORYZM LINGWISTYCZNY I NATURALISTYCZNA KONCEPCJA TREŚCI EMPIRYCZNEJ}

Podstawę empiryzmu Quine'a stanowi jego behawioryzm lingwistyczny, oparty na naturalistycznej koncepcji treści empirycznej. Jedną z ostatnich prób systematycznego przedstawienia tej koncepcji, z uwzględnieniem wszystkich kontrowersji i zarzutów nagromadzonych przez ponad 40 lat, można znaleźć w książce Pursuit of Truth ${ }^{24}$. Ideę behawioryzmu lingwistycznego trafnie zarysowuje już pierwsze zdanie: „Na podstawie bodźców odbieranych przez nasze powierzchnie sensoryczne projektujemy od pokoleń, w zbiorowym i kumulatywnym procesie twórczym, naszą systematyczną teorię świata zewnętrznego. System ten okazuje się skutecznym narzędziem przewidywania dalszych zdarzeń sensorycznych"25.

Zdaniem Quine'a podstawowym źródłem naszej wiedzy są pobudzenia sensoryczne, a ściślej - przewidywanie tych pobudzeń. W tym sensie pobudzenia sensoryczne określane są jako doznawany przez podmiot w danej sytuacji, uporządkowany według następstwa czasowego zbiór wszystkich tych jego receptorów zewnętrznych, które w tej sytuacji odbierają jakieś bodźce ${ }^{26}$.

Relacje pomiędzy pobudzeniami sensorycznymi a tworzoną naukową teorią świata są w większości wyjaśniane przez uzupełniające się nauki szczegółowe. Dla filozofii pozostaje zaś przewidywanie dalszych zdarzeń sensorycznych, które mają stanowić sprawdzian teorii naukowych ${ }^{27}$.

Ogniwem bezpośrednio łączącym pobudzenia sensoryczne $\mathrm{z}$ teorią naukową są zdania obserwacyjne, które zastępują techniczne pojęcia „obserwacji” oraz „świadectw dla nauki”. Muszą one spełniać trzy warunki:

- wywoływać natychmiastową zgodę lub niezgodę podmiotu w sytuacji pobudzenia sensorycznego,

- posiadać własność intersubiektywnej porównywalności dla wszystkich kompetentnych językowo świadków danej sytuacji,

- mieć charakter okazjonalny, czyli być prawdziwymi tylko w pewnych sytuacjach (np. „To jest łabędź”) 28 .

Quine, zdając sobie sprawę z idealizacji swoich warunków, zwrócił uwagę na stopniowalność gotowości danego podmiotu do potwierdzania zdania obserwacyjnego (np. w sytuacji spostrzeżenia czarnego łabędzia) ${ }^{29}$.

${ }^{24}$ W.V.O. Quine, Pursuit...

25 Idem, Na tropach..., s. 15.

26 Ibidem, s. 16-17.

7 Ibidem, s. 15-17.

8 Ibidem, s. 17-18.

Ibidem, s. 18. 
Następnie zostaje wprowadzona kategoria znaczenia bodźcowego. Jest nią klasa pobudzeń związanych pozytywnie lub negatywnie z danym zdaniem obserwacyjnym dla danego użytkownika języka, przy czym jest ona zbiorem wszystkich pobudzonych receptorów zewnętrznych (nie tylko wywołujących zachowania) $)^{30}$. Ponadto pobudzenia składające się na znaczenie bodźcowe muszą być dla podmiotu podobne pod względem wywoływanych zachowań prowadzących do uznawania zawsze tego samego zdania obserwacyjnego.

Odnośnie do struktury zdań obserwacyjnych Quine twierdzi, że mogą się one składać tylko z jednego wyrazu (np. „zimno”), można je także łączyć za pomocą koniunkcji lub predykacji (ta ostatnia jest koincydencją aktualnie skorelowanych nakładających się elementów w polu widzenia, np. „Ten kamyk jest niebieski”).

Zdania obserwacyjne pełnią podwójną funkcję nośnika świadectw dla nauki oraz pierwszego stadium przyswajania sobie języka przez dziecko ${ }^{31}$. Jednakże ich podstawową funkcją (której Quine dostatecznie nie uwypukla) jest łączenie języka (zarówno naukowego, jak i potocznego) z realnym światem.

Każde zdanie obserwacyjne ma podwójne oblicze, może być obciążone teorią lub od niej wolne w zależności od tego, czy jest traktowane analitycznie jako zbudowane z osobnych słów czy też jest pojmowane jako niepodzielna całość (np. „woda” i „, $\mathrm{H}_{2} \mathrm{O}$ ”). Wprowadzenie takiej ,podwójnej natury” jest możliwe tylko dzięki przyjęciu za punkt wyjścia zdań odróżnianych od terminów obserwacyjnych. Sprawiły one wiele problemów neopozytywistom, zmuszając ich do wprowadzenia „zasad łączących” zdania obserwacyjne ze zdaniami teoretycznymi ${ }^{32}$.

Kolejnym elementem systemu Quine'a są obserwacyjne zdania kategoryczne zbudowane $\mathrm{z}$ dwóch obserwacyjnych zdań okazjonalnych znajdujących się w stałej relacji. Okolicznościom opisanym w pierwszym zdaniu obserwacyjnym niezmiennie towarzyszą okoliczności opisane w drugim z nich, np. „Ilekroć występuje kruk, jest on czarny"33. Obserwacyjne zdania kategoryczne dzielą się na wolne i ogniskowe; podział ten jest analogiczny do wcześniejszego rozróżnienia na koniunkcję i predykację. Ogniskowe obserwacyjne zdanie kategoryczne uogólnia predykację i - w odróżnieniu od wolnego obserwacyjnego zdania kategorycznego uogólniającego koniunkcję - odnosi się nie tylko do tej samej sytuacji, lecz także do tego samego fragmentu tej sytuacji ${ }^{34}$.

Każde obserwacyjne zdanie kategoryczne (np. „Gdy słońce wschodzi, ptaki śpiewają") może być obalone w wyniku dwóch obserwacji: potwierdzającej oraz

\footnotetext{
30 Ibidem, s. 18-19.

Ibidem, s. 21.

Ibidem, s. 24-25.

Ibidem, s. 27-30.

4 Ibidem, s. 29-30.
} 
Pobrane z czasopisma Annales I - Philosophy and Sociology http://philosophia.annales.umcs.pl Data: 26/04/2023 15:50:37

„Niezdeterminowanie” granic poznania w znaturalizowanym relatywizmie pojęciowym... 83

zaprzeczającej. Jednakże z fałszywości obserwacyjnego zdania kategorycznego nie wynika jeszcze konkluzja o fałszywości hipotezy, w skład której ono wchodzi. Aby uratować hipotezę, można zrezygnować z jakiegoś innego zdania składowego zbioru zdań danej teorii, z którego wynika fałszywość danego obserwacyjnego zdania kategorycznego. Jest to teza głoszonego przez Quine'a umiarkowanego holizmu, którego celem jest neutralizacja fałszywych konsekwencji teorii. Jedynymi normami wyznaczającymi taką modyfikację teorii są postulaty maksymalizacji jej prostoty oraz minimalizacji jej okaleczenia ${ }^{35}$. Kwestia ta, jak pamiętamy, wiąże się $z$ atakiem Quine'a na neopozytywistyczny dogmat weryfikacjonizmu, przypisujący każdemu empirycznemu zdaniu nauki możliwość jego odrębnego sprawdzenia ${ }^{36}$.

W celu zdefiniowania treści empirycznej Quine dokonuje kolejnego podziału obserwacyjnych zdań kategorycznych na analityczne i syntetyczne. Te pierwsze występują dla danego użytkownika języka w sytuacji, gdy pozytywne znaczenie bodźcowe pierwszego składnika zdania jest zawarte w pozytywnym znaczeniu bodźcowym drugiego składnika (np. „Drozdy są ptakami”).

Brak wyżej wymienionej relacji znaczeń wskazuje na syntetyczność zdania. Zbiór zdań jest sprawdzalny, jeżeli wynikają z niego pewne syntetyczne obserwacyjne zdania kategoryczne. Jeżeli odpowiednie składniki dwóch obserwacyjnych zdań kategorycznych mają te same znaczenia bodźcowe, to zdania te są synonimiczne.

W oparciu o wprowadzone kategorie Quine definiuje treść empiryczną sprawdzalnego zdania (zbioru zdań) dla danego użytkownika języka jako zbiór wszystkich syntetycznych obserwacyjnych zdań kategorycznych, które wynikają z tego zdania (zbioru zdań) plus wszystkie zdania synonimiczne ${ }^{37}$. Kończąc omawianie „świadectw”, Quine jeszcze raz opowiada się po stronie realizmu poznawczego, stwierdzając, że celem doktryny obserwacyjnych zdań kategorycznych jest odpowiedzieć na Kantowsko-Russelowskie pytanie: Jak możliwa jest nasza wiedza o świecie zewnętrznym? Zaznacza przy tym jednak, iż odrzuca Kartezjańskie marzenie o znalezieniu mocniejszych podstaw pewności naukowej niż sama metoda naukowa lingwistycznego behawioryzmu ${ }^{38}$.

\section{NIEZDETERMINOWANIE PRZEKŁADU, ODNIESIENIA I TEORII}

Spośród wszystkich poglądów Quine'a najwięcej kontrowersji i nieporozumień spowodowały tezy o niezdeterminowaniu: przekładu, odniesienia i teorii.

\footnotetext{
35 Ibidem, s. 33-36.

36 Idem, Dwa dogmaty...

37 Idem, Na tropach..., s. 37.

38 Ibidem, s. 40.
} 
Pobrane z czasopisma Annales I - Philosophy and Sociology http://philosophia.annales.umcs.pl Data: 26/04/2023 15:50:37

Po raz pierwszy tezy te zostały sformułowane w Word and Object $^{39}$, w najbardziej rozbudowanej, ale przez to wieloznacznej formie, co stało się później przyczyną ich różnorodnych interpretacji. W odpowiedzi na te obiekcje Quine przedstawił swoje tezy w znacznie uproszczonej i jednoznacznej formie ${ }^{40}$.

$\mathrm{Na}$ początku należy podkreślić, na co zresztą zwraca uwagę sam Quine ${ }^{41}$, że teza o niezdeterminowaniu przekładu jest bezpośrednią konsekwencją powyżej przedstawionego behawioryzmu lingwistycznego. Dodaje przy tym, że o ile w psychologii można być lub nie być behawiorystą, o tyle w lingwistyce jest to swoista konieczność. Pomijając tutaj zasadność tego ostatniego stwierdzenia, przyjrzyjmy się bliżej rzeczonym „niezdeterminowaniom”.

Niezdeterminowanie przekładu. W punkcie wyjścia swojej tezy o niezdeterminowaniu przekładu Quine formułuje eksperyment myślowy nazwany radykalnym przektadem. Eksperyment ten opisuje hipotetyczną sytuację lingwisty, który wyruszył w teren, aby bez pomocy tłumacza zbadać i dokonać przekładu nieznanego dotychczas języka używanego przez ludzi żyjących do tej pory w izolacji (nazywany dalej językiem z dżungli) na swój własny język (np. polski) ${ }^{42}$. Do języka z dżungli nie istnieje dostęp za pośrednictwem żadnego znanego języka. Jedynymi danymi, jakie ma do dyspozycji ów lingwista, są wypowiedzi użytkowników tego języka wraz z towarzyszącymi tym wypowiedziom obserwowalnymi okolicznościami. Spośród tych wypowiedzi swoistymi szczelinami w językowym murze są dla lingwisty (opisane w poprzednim paragrafie) zdania obserwacyjne, czyli wypowiedzi typu: „Pada deszcz” lub „To jest królik". Lingwista próbuje skojarzyć wypowiedzi tubylców z towarzyszącą tym wypowiedziom sytuacją, aby wyodrębnić zdania obserwacyjne. Po czym, aby sprawdzić swoje przypuszczenia, kiedy dana sytuacja się powtarza, sam wypowiada dane zdanie w celu wywołania potwierdzenia lub zaprzeczenia ze strony tubylców. Jeżeli eksperymenty kończą się sukcesem, lingwista tworzy listę potwierdzonych zdań obserwacyjnych. Stopniowo do tej listy będzie on dołączał coraz to nowe typy wyrażeń języka z dżungli oraz ich odpowiedników z języka polskiego (wszystkie typy takich wyrażeń zostały przedstawione w poprzednim paragrafie). W wyniku takiego postępowania, po pewnym czasie,

\footnotetext{
39 Idem, Word and Object, Cambridge 1960; idem, Stowo i przedmiot, Warszawa 1999.

40 Zob. m.in. idem, Three Indeterminacies, [w:] R.B. Barrett, R.F. Gibson (eds.), Perspectives on Quine, Oxford 1989; idem, Trzy niezdeterminowania, [w:] B. Stanosz (red.), Filozofia języka, Warszawa 1993; idem, Indeterminacy of Translation Again, "Journal of Philosophy" 1987, Vol. 84(1), DOI: https://doi.org/10.2307/2027132; idem, Raz jeszcze o niezdeterminowaniu przektadu, [w:] B. Stanosz (red.), op. cit.

${ }^{41}$ Ibidem, s. 194.

42 Idem, Stowo..., s. 41.
} 
Pobrane z czasopisma Annales I - Philosophy and Sociology http://philosophia.annales.umcs.pl Data: 26/04/2023 15:50:37

„Niezdeterminowanie” granic poznania w znaturalizowanym relatywizmie pojęciowym..

lingwiście uda się zbudować kompletny zbiór (podręcznik) zasad przekładu języka z dżungli na język polski. Świadectwem poprawności dla tego podręcznika będzie praktyczna skuteczność w komunikowaniu się z tubylcami. Niezdeterminowanie przekładu pojawi się w sytuacji, kiedy dwaj lingwiści, dokonując niezależnie radykalnego przekładu języka tego samego plemienia dżungli, zbudują wzajemnie wymienialne podręczniki przekładu. Podręczniki te mogą nie różnić się niczym, co dotyczy zachowań, których można oczekiwać u użytkowników języka, a mimo to każdy z nich może wskazywać przekłady, które drugi tłumacz

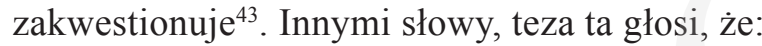

[...] twierdzenia o dwóch podręcznikach mogą być równocześnie prawdziwe, podczas gdy ustalonych przez nie relacji przekładu nie można używać na przemian bez otrzymywania zdań niespójnych. Mówiąc inaczej: zdania naszego własnego języka, wskazane przez dwa konkurencyjne podręczniki jako przekłady danego zdania języka z dżungli, mogą nie być wzajemnie wymienialne we wszystkich kontekstach naszego języka ${ }^{44}$.

Quine zauważa ponadto, że teza o niezdeterminowaniu przekładu może być odniesiona nawet do naszego własnego języka w przypadku, kiedy za pomocą jednego podręcznika dokonujemy przekładu języka polskiego na język z dżungli, a później z powrotem z języka z dżungli na język polski za pomocą drugiego podręcznika. W efekcie otrzymujemy sprzeczność naszego języka ${ }^{45}$.

Niezdeterminowanie odniesienia. Swoistym symbolem tezy o niezdeterminowaniu przekładu stało się słowo „Gavagai”. Jednak Quine sam przyznaje, że słowo to nie zostało przez niego ukute dla zilustrowania niezdeterminowania przekładu w wąskim sensie. Słowo „Gavagai” jako zdanie obserwacyjne jest dokładnie i całościowo przekładalne na „(Patrz) królik”. Jednakże przekład ten nie jest wystarczający do ustalenia odniesienia „gavagai” jako terminu, ponieważ nie ma pewności, że termin ten odnosi się do królików, a nie np. tylko do „etapów królika” albo „czasowo przestrzennego przekroju królika” lub po prostu „Coś bym zjad’” (przykład dr W. Martyny). Wyłącznie temu miał właśnie służyć eksperyment ze słowem „Gavagai”. Słowo to stanowi skrajny przykład niezdeterminowania odniesienia w sytuacji, gdy termin występujący w zdaniu jest zarazem całym tym zdaniem. W przypadku niezdeterminowania przekładu niezdeterminowanie odniesienia jest pewną formą opisanej wcześniej względności ontologicznej i wiąże się z możliwymi wyborami alternatywnych podręczników przekładu. Zatem stwierdzenie, że „gavagai” denotuje króliki, jest aktem wyboru tego pod-

${ }^{43}$ Idem, Raz jeszcze..., s. 195-197.

44 Idem, Trzy niezdeterminowania, s. 125-126.

45 Idem, Na tropach..., s. 81-82. 
Pobrane z czasopisma Annales I - Philosophy and Sociology http://philosophia.annales.umcs.pl Data: 26/04/2023 15:50:37

86 Andrzej Kubić

ręcznika przekładu spośród alternatywnych podręczników, w którym „gavagai” thumaczone jest jako „królik”"46.

W praktyce, aby uniknąć paradoksalnych konsekwencji przekładu, lingwiści muszą założyć, że kategorie myślenia tubylców są podobne do ich własnych. Teza o niezdeterminowaniu przekładu dowodzi niemożliwości funkcjonowania uniwersalnej teorii znaczeń wykraczających poza wewnątrzjęzykowe uwarunkowania. Quine postuluje usunięcie problemu znaczenia z filozofii, ponieważ do jego rozwiązania wystarczy leksykografia, której zadaniem jest pokazywanie sposobów posługiwania się wyrażeniami w danym języku ${ }^{47}$.

Niezdeterminowanie teorii. Teorie (lub sformułowania teorii) mogą być logicznie niezgodne, a równocześnie empirycznie równoważne. Dowodzi tego zastosowanie opisanych wcześniej funkcji pełnomocnictwa, które pokazują, że teorie mogą mieć całkiem różne przedmioty będące wartościami ich kwantyfikowanych zmiennych przy jednoczesnej równoważności treści empirycznej. Dobrym przykładem mogą tu być geometrie B. Riemanna i Euklidesa zastosowane do powierzchni kuli. Według teorii Riemanna proste zawsze się przecinają, natomiast według teorii Euklidesa niektóre się przecinają, a inne nie oraz na powierzchni kuli nie ma prostych. Konflikt między tymi teoriami można usunąć poprzez zreinterpretowanie w geometrii Riemanna terminu „prosta” na termin „wielkie koło”.

Inaczej wygląda sytuacja, kiedy mamy do czynienia z teoriami równoważnymi zarówno pod względem empirycznym, logicznym, jak i ekonomicznym, zawierającymi jednak pewne nieredukowalne i niereinterpretowalne wzajemnie terminy („entelechia”, „łaska”, „nirwana”). Quine mówi o dwóch podstawowych postawach, jakie można zająć wobec takiej sytuacji. Pierwszą, według której należy pozostać przy dotychczas uznawanej teorii (jako jednej z tych alternatywnych), określa mianem sekciarskiej. Drugą zaś, zaproponowaną przez D. Davidsona, nazywa ekumeniczna. W perspektywie postawy ekumenicznej obie teorie traktujemy jako prawdziwe $\mathrm{z}$ osobna, przy czym predykat prawdy jest tu rozumiany jako usuwanie cudzysłowów w pewnym obszerniejszym i neutralnym języku, w którym wyrażone są obie teorie. Te dwie postawy wydają mu się również równoważne, gdyż nie ma racji, które by bardziej przemawiały za jedną z nich.

Quine mówi o ewidentnej paraleli między empirycznym niezdeterminowaniem globalnej teorii świata i niezdeterminowaniem przekładu. To ostatnie pokazuje, że koncepcja sądów jako znaczeń zdań jest nie do utrzymania, natomiast drugie

46 Idem, Trzy niezdeterminowania, s. 126-127; idem, Na tropach ..., s. 86-87.

47 Idem, Trzy niezdeterminowania, s. 93-97. 
Pobrane z czasopisma Annales I - Philosophy and Sociology http://philosophia.annales.umcs.pl Data: 26/04/2023 15:50:37

„Niezdeterminowanie” granic poznania w znaturalizowanym relatywizmie pojęciowym... 87

uwidacznia, że istnieją rozmaite dające się obronić sposoby ujmowania świata. Podkreśla przy tym, że takie konkurencyjne teorie opisują jeden i ten sam świat ${ }^{48}$.

Quine wysuwa na koniec tezę, której nie rozwija, a która jest bardzo istotna z punktu widzenia zagadnienia granic poznania. „Wizja nierozstrzygalnie konkurencyjnych systemów świata - jak pisze - jest eksperymentem myślowym wykraczającym poza obszary naszego wykrystalizowanego w użyciu sposobu mówienia”49. I nieco dalej: „Dyspozycje do obserwowalnych zachowań są dla semantyki wszystkim, co do czego można mieć rację lub mylić się. W przypadku systemów świata natomiast jesteśmy skłonni sądzić, że rzeczywistość wykracza w bliżej nieokreślony sposób poza zasięg aparatu poznawczego człowieka"s0.

\section{MENTALIZM W CUDZYSŁOWIE I PRAWDA BEZ CUDZYSŁOWU}

Mentalizm. Z perspektywy swojego behawioryzmu lingwistycznego Quine rozpatruje również zagadnienia wchodzące $\mathrm{w}$ zakres specyficznie rozumianego mentalizmu. Twierdzi, że podstawową cechą wypowiedzi mentalistycznych jest ich kontekst intensjonalny $\mathrm{w}$ przeciwieństwie do ekstensjonalnego kontekstu twierdzeń nauki.

Wszystkie niezwiązane z pobudzeniami zmysłowymi oraz zdaniami obserwacyjnymi akty i czynności umysłowe zalicza do „postaw propozycjonalnych”. Do klasy tej należą zwroty typu: „,postrzega, że p.”, ,wierzy, że p.”, ,ma nadzieję, że p.”, „żałuje, że p.”, „obawia się, że p.”, „mówi, że p.”. Znaki cudzysłowu symbolizują nieprzenikalną przegrodę pomiędzy dwiema ontologiami: osoby żywiącej daną postawę i osoby przypisującej jej tę postawę. W ten sposób przeformułowane postawy propozycjonalne są analizowalne jedynie przez literowanie, czyli syntaktycznie. Określone są mianem de dicto $\mathrm{i}-\mathrm{w}$ odróżnieniu od naturalnych postaw propozycjonalnych de re - mogą one być włączone do języka nauki, nie stwarzając zagrożenia pomieszania kontekstu ekstensjonalnego $\mathrm{z}$ intensjonalnym ${ }^{51}$.

Quine, podkreślając fundamentalną rolę części postaw propozycjonalnych $\mathrm{w}$ tworzeniu komunikacji językowej (rozpoznawanie cudzych percepcji oraz przekonań), odrzuca jednocześnie jako zbędną resztę „mentalistycznego dziedzictwa". Podstawowe pojęcia mentalistyczne są jego zdaniem wynikiem subiektywnych projekcji uwikłanych w codzienną praktykę społeczno-biologiczną ${ }^{52}$.

\footnotetext{
48 Idem, Na tropach ..., s. 146-155.

49 Ibidem, s. 153.

50 Ibidem, s. 154-155.

51 Ibidem, s. 108-113.

52 Ibidem, s. 118-119.
} 
Prawda. W epistemologii Quine'a funkcjonuje kategoria prawdy, chociaż - jak wynika z tego, co wcześniej powiedziano - musi ona być „pozbawiona znaczenia". Wyróżnić więc można dwa zasadniczo przeciwstawne ujęcia tego problemu. Według pierwszego nośnikami prawdy i fałszu są zdania, natomiast według drugiego - sądy, czyli znaczenia zdań. W oparciu o swoją tezę o niezdeterminowaniu przekładu Quine odrzuca drugie ujęcie, opowiadając się za przyjęciem zdań jako nośników prawdy. W tym celu wprowadza kategorię „zdań wiecznych”, które są zdaniami oznajmującymi o stałej wartości logicznej, niezależnymi od czasów gramatycznych, stanowiącymi powtarzalną formę językową, np. „Śnieg jest biały”. Chociaż Quine nie mówi tego wprost, można przypuszczać, że „zdania wieczne" stanowią inne sformułowanie ogniskowych kategorycznych zdań obserwacyjnych.

Modyfikując semantyczną teorię prawdy A. Tarskiego, Quine formułuje swoją wersję korespondencyjnej teorii prawdy, według której przypisanie prawdziwości zdaniu wiecznemu polega na pominięciu znaków cudzysłowu: „prawda jest usunięciem cudzysłowów". Nazwanie zdania prawdziwym polega po prostu na uznaniu go. Przymiotnik prawdziwy (predykat prawdziwości) jest zbędny; gdy orzeka się go o danym zdaniu, wystarczy wypowiedzieć to zdanie. Przykładowo zdanie „Śnieg jest biały” jest prawdziwe wtedy i tylko, gdy śnieg jest biały ${ }^{53}$. W literaturze przedmiotowej jest ona określana jako koncepcja dyskwotacyjna ${ }^{54}$.

Jednakże predykat prawdziwości jest niezbędny przy stosowaniu generalizacji w zakresie wykraczającym poza termin ogólny, np. „Wszystkie zdania mające formę »Jeśli $\mathrm{p}$, to q « są prawdziwe". Takie sformułowanie nie jest jednak w stanie uniknąć antynomii kłamcy, gdyż zawiera predykat prawdy. Zdaniem Quine'a istnieje sposób na uniknięcie paradoksów poprzez wprowadzenie hierarchii zmiennych reprezentujących klasy i hierarchii predykatów prawdy, objętych jednym wspólnym językiem. W efekcie miałby powstać spójny język z hierarchią coraz lepszych predykatów ${ }^{55}$.

W ramach swojej teorii prawdy, głęboko osadzonej w logice dwuwartościowej, Quine broni prawa wyłączonego środka. Odrzuca więc logiki modalne i wielowartościowe, dokonując jednocześnie rozróżnienia pomiędzy prawdą a pewnością przekonań. Jego zdaniem można uznać za sensowne również prawdy czystej matematyki, a to ze względu na sformułowanie ich w ramach tej samej gramatyki i tego samego słownika, z działami matematyki znajdującymi empiryczne zastosowanie.

53 Ibidem, s. 125.

54 J. Woleński, Metamatematyka ..., s. 188-189.

55 W.V.O. Quine, Na tropach..., s. 138-139. 
Pobrane z czasopisma Annales I - Philosophy and Sociology http://philosophia.annales.umcs.pl Data: 26/04/2023 15:50:37

„Niezdeterminowanie” granic poznania w znaturalizowanym relatywizmie pojęciowym...

\section{PYTANIE O PRZEDMIOT I PSEUDO-PYTANIE O GRANICE POZNANIA}

W sposób syntetyczny swoją koncepcję przedmiotu Quine przedstawił $\mathrm{w}$ Things and Their Place in Theories ${ }^{56}$. Tekst rozpoczyna następująca ogólna teza:

Nasze mówienie o rzeczach zewnętrznych, a nawet sama koncepcja rzeczy, jest po prostu aparatem pojęciowym [podkr. - A.K.], który pomaga nam przewidywać i kontrolować pobudzenia naszych receptorów zmysłowych w świetle wcześniejszych pobudzeń naszych receptorów zmysłowych. Pobudzenia są ostatecznie wszystkim, co pozwala nam posuwać się naprzód ${ }^{57}$.

Kategoria przedmiotu fizycznego jest tu zdefiniowana (z uwzględnieniem stanu współczesnej fizyki) jako materialna zawartość każdej porcji czasoprzestrzeni, bez względu na nieregularność, nieciągłość i heterogenicznośćs ${ }^{8}$. Jeżeli do tak zliberalizowanego pojęcia przedmiotu fizycznego dołączy się równie liberalne pojęcie przedmiotu abstrakcyjnego sprowadzonego do kategorii klas, to według Quine'a całą ontologię można zredukować do teorii mnogości (należy podkreślić, że w takim ujęciu wszystkie przedmioty uzyskują status teoretyczny).

Dopiero przy tak zredukowanej koncepcji przedmiotu można zrozumieć, jak możliwy jest Quine’owski relatywizm ontologiczny. Innymi słowy, zaproponowana przez niego „ontologiczna reinterpretacja redukcyjna” pozwala zrezygnować z jednej z dwóch dziedzin przedmiotowych odnoszących się do tych samych wrażeń (pobudzeń) zmysłowych. Wybór ontologii (schematu pojęciowego) opiera się na kryteriach pragmatycznych: używamy tych „mostów pojęciowych”, które lepiej łączą pobudzenia zmysłowe z kolejnymi pobudzeniami zmysłowymi.

Ponieważ w ujęciu tym prawda jest immanentna (wewnętrzna) dla każdej ontologii (teorii, schematu pojęciowego), nie można - zdaniem Quine'a - przyjąć zewnętrznego punktu widzenia, umożliwiającego stwierdzenie, że każda $\mathrm{z}$ tych ontologii jest prawdziwa na swój sposób oraz że wszystkie przedstawione w tych ontologiach światy są realne. Jedyną możliwość oceny alternatywnych ontologii daje przytoczona powyżej płaszczyzna pragmatyczna. To samo dotyczy pojęcia faktu, który również staje się kategorią wewnątrzteoretyczną, czyli uzależnioną od przyjętej ontologii.

56 Idem, Things and Their Place in Theories, [w:] Theories and Things, Cambridge 1981; idem, Rzeczy i ich miejsce $w$ teoriach, [w:] T. Szubka (red.), Metafizyka w filozofii analitycznej, Lublin 1995.

57 Ibidem, s. 31.

58 Ibidem, s. 39. 
Pobrane z czasopisma Annales I - Philosophy and Sociology http://philosophia.annales.umcs.pl Data: 26/04/2023 15:50:37

W konsekwencji Quine zmuszony jest dopuścić możliwość radykalnego sceptycyzmu wobec ontologii naukowej (naukowego obrazu świata). Mówiąc inaczej, naukowa skuteczność przewidywania obserwacji może bardzo się zmniejszyć (a nawet zaniknąć) przy jednoczesnym wzroście skuteczności opierania przewidywań na snach czy marzeniach ${ }^{59}$.

W filozofii Quine'a znika więc transcendentalne pytanie o rzeczywistość świata zewnętrznego - zagadnienie: czy (lub jak dalece) nasza wiedza sięga do Ding an sich. Jedyną granicę, a zarazem podstawę, alternatywnych form wiedzy stanowią tu zatem pobudzenia bodźcowe (stimulation), będące jednocześnie jedyną przyczynową relacją gwarantującą istnienie świata zewnętrznego.

Zatem Quine bezpośrednio podejmuje zagadnienie granic poznania w postaci lingwistycznie zreinterpretowanego pytania: Czy są pytania, na które z zasady nie można odpowiedzieć? Następnie odrzuca je jako bezsensowne. Negacja ta jednak nie dotyczy pytania o zakres i naturę przedmiotu poznania (czyli: Co jest poznawalne?), które - odniesione do koncepcji Quine'a - pozwala umiejscowić ją w gronie teorii przyjmujących, że rzeczywistość jest całkowicie poznawalna $R \equiv p$ oraz dokonania bardziej szczegółowych ustaleń. I tak w sporze realizmu teoriopoznawczego z idealizmem teoriopoznawczym Quine ze swoim instrumentalizmem i teoretycznym statusem wszystkich przedmiotów musi opowiedzieć się po stronie tego ostatniego. Analogicznie jest w perspektywie sporu o naturę przedmiotu poznania (ontologiczne tworzywo świata) - wszystkie przedmioty uzyskują status teoretyczny. Jednocześnie jednak Quine jest realistą ontologicznym, ponieważ jedyną granicę, a zarazem podstawę, alternatywnych form wiedzy stanowią tu pobudzenia bodźcowe (stimulation), będące jedyną przyczynową relacją gwarantującą istnienie świata zewnętrznego. W odniesieniu do sporu o uniwersalia stanowisko Quine'a jest określane jako konkretyzm (przyjmował jednostkowe byty abstrakcyjne teorii mnogości $\left.{ }^{60}\right)$.

W kwestii podmiotu poznania Quine przyjmuje poglądy redukcjonistycznego naturalizmu i behawioryzmu. Przyjęta przez niego dyskwotacyjna („odcudzysłowieniowa”) koncepcja prawdy (zaliczana do teorii redundancyjnych) jako kategoria wewnąrzteoretyczna niewiele ma wspólnego z teorią klasyczną. W sprawie

\footnotetext{
59 Ibidem, s. 50.

${ }^{60}$ Według U. Żegleń Quine ,,bronił ontologii opisanej w języku ekstensjonalnym i można sądzić, że opartej na założeniach nominalistycznych, choć sprawa nominalizmu nie była u Quine'a całkiem jednoznaczna i w matematyce można go było nawet uważać w pewnym sensie za platonistę. Nie jest to sztandarowy platonizm wynikający z przekonań ontologicznych, lecz wymuszony przez najlepsze teorie naukowe, które wymagają kwantyfikacji przebiegającej przez obiekty abstrakcyjne. Z ducha jednak pozostał Quine nominalistą [...]". Zob. U. Żegleń, Filozofia z punktu widzenia Quine'a, „Ruch Filozoficzny” 2001, nr 2, s. 211.
} 
prawomocności poznania Quine paradoksalnie był jednocześnie „,apriorycznym antyfundamentalistą" - mamy do wyboru wiele równoważnych, pod względem epistemologicznym, systemów pojęciowych, i „empirycznym fundamentalistą" przyjął naturalistyczną koncepcję treści empirycznej, zredukowaną do bodźców odbieranych przez nasze powierzchnie sensoryczne, czyli treści określonej przez założenie nadrzędności stanowiska behawioryzmu lingwistycznego.

\section{BIBLIOGRAFIA}

Ajdukiewicz K., Logika i doświadczenie, „Przegląd Filozoficzny” 1947, nr 1-4.

Grice P., Strawson P., In Defense of a Dogma, "The Philosophical Review” 1956, Vol. 65(2), DOI: https://doi.org/10.2307/2182828.

Jakubiec H., Woleński J., Ajdukiewicz a Quine, „Zagadnienia Naukoznawstwa” 1983, nr 3.

Quine W.V.O., Dwa dogmaty empiryzmu, [w:] Z punktu widzenia logiki, Warszawa 2000.

Quine W.V.O., Granice wiedzy, [w:] Granice wiedzy i inne eseje filozoficzne, Warszawa 1986.

Quine W.V.O., Indeterminacy of Translation Again, "Journal of Philosophy" 1987, Vol. 84(1),

DOI: https://doi.org/10.2307/2027132.

Quine W.V.O., Methods of Logic, Cambridge 1982.

Quine W.V.O., Na tropach prawdy, Warszawa 1997.

Quine W.V.O., O tym, co istnieje, [w:] Z punktu widzenia logiki, Warszawa 2000.

Quine W.V.O., Ontological Relativity and Other Essays, Cambridge-London 1977.

Quine W.V.O., Pursuit of Truth, Cambridge 1992.

Quine W.V.O., Raz jeszcze o niezdeterminowaniu przekładu, [w:] B. Stanosz (red.), Filozofia języka, Warszawa 1993.

Quine W.V.O., Rzeczy i ich miejsce w teoriach, [w:] T. Szubka (red.), Metafizyka w filozofii analitycznej, Lublin 1995.

Quine W.V.O., Stowo i przedmiot, Warszawa 1999.

Quine W.V.O., The Limits of Knowledge (1972), [w:] The Ways of Paradox and Other Essays, Massachusetts-London 1976.

Quine W.V.O., Things and Their Place in Theories, [w:] Theories and Things, Cambridge 1981.

Quine W.V.O., Three Indeterminacies, [w:] R.B. Barrett, R.F. Gibson (eds.), Perspectives on Quine, Oxford 1989.

Quine W.V.O., Trzy niezdeterminowania, [w:] B. Stanosz (red.), Filozofia języka, Warszawa 1993.

Quine W.V.O., Two Dogmas of Empiricism, "Philosophical Review" 1951, Vol. 60(1),

DOI: https://doi.org/10.2307/2181906.

Quine W.V.O., Word and Object, Cambridge 1960.

Woleński J., Epistemologia, t. 2: Wiedza i poznanie, Kraków 2001.

Woleński J., Metamatematyka i epistemologia, Warszawa 1993.

Żegleń U., Filozofia z punktu widzenia Quine’a, „Ruch Filozoficzny”2001, nr 2.

\section{SUMMARY}

The article presents a naturalized conceptual relativism of W.V.O. Quine in the perspective of the limits of knowledge. Quine was at the same time a conceptual relativist (we have many equivalent epistemological conceptual systems) and an empirical naturalist (he adopted a naturalistic concept of empirical content reduced to the stimuli received by our sensory surfaces as a part of 
Pobrane z czasopisma Annales I - Philosophy and Sociology http://philosophia.annales.umcs.pl Data: 26/04/2023 15:50:37

linguistic behaviorism). Quine also directly addressed the issue of the limits of knowledge, but his main intention - as he points out - was above all the analysis and modification of the title problem, not the attempt to answer them. In short, according to Quine, this problem can be reduced to the linguistic context.

Keywords: limits of knowledge; conceptual relativism; empiricism; naturalism; linguistic behaviorism

\section{STRESZCZENIE}

W artykule opisano znaturalizowany relatywizm pojęciowy W.V.O. Quine'a w perspektywie problematyki granic wiedzy. Quine był jednocześnie relatywistą pojęciowym (mamy do wyboru wiele równoważnych pod względem epistemologicznym systemów pojęciowych) i empirycznym naturalistą (przyjmował naturalistyczną koncepcję treści empirycznej zredukowanej do pobudzeń odbieranych przez nasze powierzchnie sensoryczne w ramach behawioryzmu lingwistycznego). Ponadto bezpośrednio podejmował zagadnienie granic wiedzy, jednak jego główną intencją - jak sam zaznaczył - była przede wszystkim analiza i modyfikacja tytułowego problemu, a nie próba udzielenia na niego odpowiedzi. Krótko mówiąc, zdaniem Quine'a zagadnienie to można zredukować do kontekstu językowego.

Słowa kluczowe: granice wiedzy; relatywizm pojęciowy; empiryzm; naturalizm; behawioryzm lingwistyczny 